Goldschmidt 2021 Abstract

https://doi.org/10.7185/gold2021.7335

\section{Geochemical variation of magmatic Fe-Ti-P mineralization associated with Proterozoic massif-type anorthosites from the Grenville Province, Quebec: tracking magma differentiation using oxide, apatite and plagioclase chemistry of the Vanel Anorthosite Suite}

\author{
PEDRO MILOSKI ${ }^{1}$, SARAH A. S. DARE ${ }^{2}$ AND CAROLINE \\ EMMANUELLE MORISSET ${ }^{3}$ \\ ${ }^{1}$ University of Quebec at Chicoutimi (UQAC) \\ ${ }^{2}$ Universite du Quebec a Chicoutimi (UQAC) \\ ${ }^{3}$ Canadian Space Agency
}

Presenting Author: miloski.geo@gmail.com

Magmatic oxide-apatite mineralization is spatially and temporally associated with Proterozoic massif-type anorthosites, providing important resources for $\mathrm{TiO}_{2}$ (hemo-ilmenite: $\mathrm{Fe}_{2} \mathrm{O}_{3}$ $\mathrm{FeTiO}_{3}$ ), $\mathrm{V}$ (magnetite: $\mathrm{Fe}_{3} \mathrm{O}_{4}$ ) and $\mathrm{P}$ (apatite: $\left.\mathrm{Ca}_{5}\left(\mathrm{PO}_{4}\right)_{3}(\mathrm{OH}, \mathrm{F}, \mathrm{Cl})\right)$. For example, the world's largest producer of $\mathrm{TiO}_{2}$, Lac Tio mine, is a hemo-ilmenite-deposit within the anorthosite massif of Havre St. Pierre, Quebec. However, the origin and genetic relationship of both the anorthosite host and oxide-apatite mineralization are still highly debated, as well as the exact tectonic setting. The type of oxide mineralogy (Timagnetite, ilmenite, hemo-ilmenite) appears to vary with the composition of plagioclase of the massif anorthosite (labradorite or andesine) which may relate to different parental melts and/or degrees of crustal contamination during emplacement of plagioclase rich-mushes into the crust $[1,2]$. In the Grenville Province, Quebec, the oxide mineralogy generally changes as a function of the anorthosite age: andesine-type anorthosites that are younger than $1100 \mathrm{Ma}$ are orthopyroxene-bearing and host hemo-ilmenite mineralization, whereas labradorite-type anorthosites are older than $1100 \mathrm{Ma}$, are olivine-bearing and host Ti-magnetite mineralization $[3,4]$. The aim of this research is to improve our understanding of what causes these changes with time by studying the mineralogical and geochemical variation (whole-rock and trace-element mineral chemistry) of different Fe-Ti-P mineralization, here associated with the 1.06Ga Vanel Anorthosite Suite, Central Grenville. A detailed stratigraphical study of silicates (Fig.1), oxides and apatite for the Lac à L'Orignal Ti-P occurrence reveals geochemical variation related to magma differentiation within a single mineralized body. Comparison with nearby, coeval oxide-apatite-rich occurrences (Lac Mirepoix, Lac Périgny and Lac de L'Abbondance) provides an opportunity to evaluate the role of fractional crystallization, magma dynamics and assimilation of crustal rocks in forming Ti$\mathrm{P}$ deposits in anorthosite massifs.

[1] Morse, S. A. 2006. Lithos, 89(1 2), 202-221.

[2] Woodruff, L. G., Nicholson, S. W., Fey, D.L. 2013. USGS Report 2013-5091 (47 pp.).

[3] Corriveau, L., Perreault, S., Davidson, A., 2007.
Geological Survey of Canada, Special Publication, pp. 819-847.

[4] Hébert, C., Van Breemen, O., Cadieux, A. M., \& Gosselin, C. 2009. Synthèse géologique. Ressources naturelles et faune, Québec.

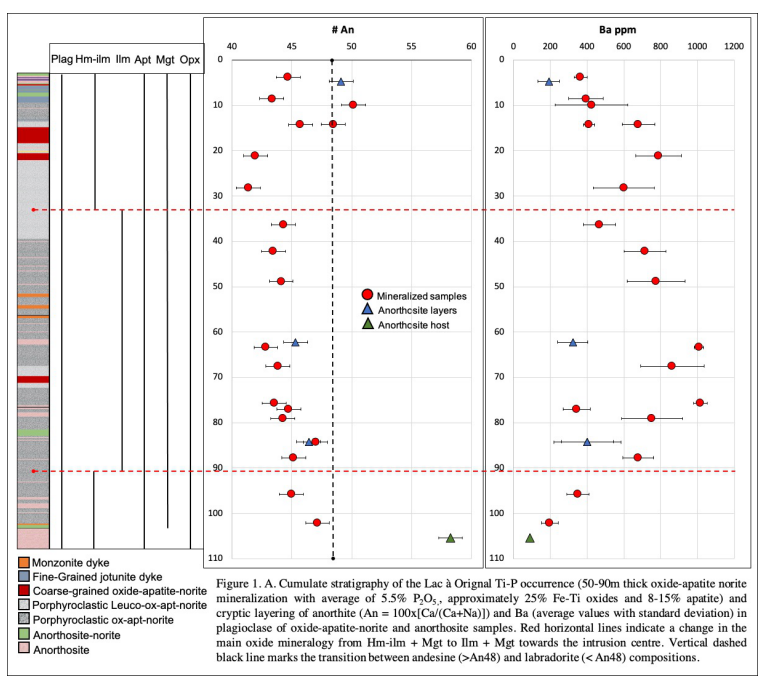

